\title{
Critical analysis of applicability of Shadanga Paneeya in Jwara Chikitsa: A Review
}

\author{
Review Article
}

\section{Srinivas Avula1*}

1. Associate Professor/Reader, Department of Samhita Siddhanta, Raja Rajeshwari Ayurvedic Medical College and Hospital, Humnabad, Bidar District, Karnataka.

\begin{abstract}
Jwara is one of the dreadful diseases, which affects the human body, mind as well as senses. The jwara has been described in all the classics of Ayurveda with prime importance. The fever has been described in detail with its etiology, pathology, sign symptoms, and management. Diet is being equally important as that of medicine. Jwara occurs due to the depletion of the digestive fire leading to the formation of aama. In Charak samhita different diet and drinks have been described as per the condition of jwara. Siddha jala (medicated drinks) has been described in jwara such as Ushna jala in vata kapha jwara, Tiktaka shruta sheeta jala in madyaja and paittika jwara, Shadanga Paneeya in all kinds of jwara. Shadanga paneeya has been described as useful in all kinds of jwara. Shadanga contains six drugs, viz., Musta (Cyperus rotundus Linn), Parpatak (Fumaria parviflora Lam.), Usheera (Vetiveria zizanoides (Linn) Nash.), Chandana (Santalum album Linn.), Uddichya (Pavonia odorata Willd), Nagar (Zingiber officinale Roscoe). This combination is unique, and helpful in all kinds of jwara. The drug possessing the properties of sheeta veerya and tikta, katu rasa, by virtue of which they are useful in pacifying the jwara. Therefore, here an attempt is made to understand the applicability of Shadanga paneeya in all kinds of jwara.
\end{abstract}

Key Words: Jwara, Shadanga paneeya, Fever.

\section{Introduction}

Samhitas are the source of knowledge of Ayurveda. In order to achieve the four pursuits of life Ayurveda helps to maintain the health and cure the disease. Diseases are described in Samhitas with their etiology, sign symptoms and management. Jwara (fever) is the disease which present at the time of birth and death also. Jwara is considering as important disease as it afflicts the body, mind and senses.

In Charaka samhita jwara has been described with its etiology, sign symptoms and management principle in Nidanasthana, whereas its detailed management with different types described in chikitsasthana. $(1,2)$ Different treatment modalities has been described for the jwara. As Agni dushti is the prime cause in manifestation of jwara. Diet is being equally important as that of medicine. Jwara occurs due to the depletion of the digestive fire leading to the formation of aama. In Charak samhita different diet and drinks have been described as per the condition of jwara. Siddha jala (medicated drinks) has been

* Corresponding Author:

\section{Srinivas Avula}

Associate Professor/Reader,

Department of Samhita Siddhanta, Raja Rajeshwari Ayurvedic Medical College and Hospital,

Humnabad, Bidar District, Karnataka.

Email Id: srinivasonu16@,gmail.com described in jwara such as ushna jala in vata kapha jwara, tiktaka shruta sheeta jala in madyaja and paittika jwara, shadanga Paneeya in all kinds of jwara. Shadanga contains six drugs, viz., Musta, Parpatak, Usheera, Chandana, Uddichya, Nagar. This combination is unique, and helpful in all kinds of jwara.
Aim
To understand the applicability of Shadanga Paneeya in all kinds of Jwara.

\section{Material and methods}
For this conceptual study Ayurveda Samhitas - Charaka Samhita, Sushruta Samhita, Bhavaprakash nighantu books of Dravyaguna vignana, and online journals in which study of the concern drug has been carried out have been re-viewed.
Limitation: The data published in different articles about these drugs has been studied in vitro, no human trials had been done, so here interpretation has made on the basis of that data.

\section{Observations}
Charaka samhita and Sushruta samhita both consider the origin of jwara is from lord Shiva. Jwara is considered as supreme among all the diseases named by different name in different creature. $(4,5)$ Due to presence of devotional power in human being they can tolerate the fever, but rest of all animals could not survive once get afflicted by fever. (5) 
Etiopathogenesis of fever

\section{Nidana(Causitive factor)}

Charaka samhita: (6) In nidanasthana there is description about eight types of jwara.The Strotas involved in occurrence of jwara is Rasavaha and Swedavaha. Nidana, samprapti and laxanas have been described separately for vataj, pittaja, kaphaja, Dwandaja, sannipataja jwara.Vishamprajanana and prajata mithyopachara are also elaborated as a causes for jwara.

In Sushruta samhita the common causative factor for all kinds of jwara has been described viz., Snehadi karma mithyayoga (improper application of oleation, sudation, ), atiyoga(excees application of oleation, sudation), Abhighat(Trauma), Rogotthana prapakata(at the occurrence of disease), shrama(fatigue), kshaya(wasting of body tissues), ajeerna(indigestion), visha(poison), satmya viparyaya(ingestion of unwholesome food), rutu viparyaya(not following the seasonal regimen), oushadhi pushpa gandha(inhale the medicated flowers), shoka(grief), nakshatrapeeda(curse of stars), abhichar(improper social behaviour), abhishap(curse from other people), manasika abhishang(psychological distrurbances), Apprajata(not having normal labour), ahita sevan prajata(not following the post natal care), stanyaavataran(lactation).(7)

\section{Purvarupa (Prodromal sign)}

In Charaka samhita the prodromal signs of fever have been described as, aalasya, nayanasrava, jrumbha, gourava, klama, bhakta dwesha, avipaka, aasyavairasya, balahani, varnahani, alpa sheela vaikruta.(8)

The general prodromal sign and symptoms have been described in Sushruta samhita, along with the specific prodromal sign and symptoms in concern with involved doshas are described.

- Vata-jrumbha (yawning)

- Pitta- nayan dah (burning sensation in eyes )

- Kapha- na anna abhinandan(no desire for food)

The sign and symptoms of vataj pittaja and kaphaja jwara have been described in detail. Dwandwaja jwaras description has been also described. (9)

\section{Jwara samanya laxana}

Swedavrodha, Santap, Sarvangagrahan.

Jwara samprapti:

Charaka samhita describes the samprapti of jwara with its nidana in detail with individual type in nidanasthana. Furthermore in chikitsasthana the common samprapti have been described.

In Sushruta samhita common samprapti have been described. The vitiated doshas when pulls out the aamaashaya ushma into rasavaha and swedavaha strotas. The obstruction occurs in a strotas, agni get diminished, and manifest the jwara.

\section{Samanya jwara chikitsa}

The principles of jwara chikitsa have been described in both samhitas.

Table no. 1

\begin{tabular}{l|l|l|}
$\begin{array}{l}\text { Stage } \\
\text { Purvarupa }\end{array}$ & Charaka Samhita(10) & $\begin{array}{l}\text { Sushruta samhita (11) } \\
\text { Vataj- Pure ghee } \\
\text { Pittaj-Virechana } \\
\text { Kaphaja-Mrudu Prachachardhana }\end{array}$ \\
\hline $\begin{array}{l}\text { Aamashaya } \\
\text { samuttha: }\end{array}$ & $\begin{array}{l}\text { kashayapana, abhyanga, sneha, sweda, } \\
\text { pradeha, parisheka, lepana, vaman, virechana, } \\
\text { aasthapana, anuvasan, } \\
\text { nasya, dhupa, dhuma, ksheerabhojana. }\end{array}$ & $\begin{array}{l}\text { Apatarpan, Vaman, Langhana, Ushnambu } \\
\text { Vamana, Aasthapana, shirovirechana }\end{array}$ \\
\hline Jeerna jwara: & $\begin{array}{l}\text { Sarpi pana } \\
\text { Sarpi pana }\end{array}$
\end{tabular}

Table no. 2: Siddha jala (Medicated drinks) to be administered in jwara

Ushna jala

Tiktaka shruta sheeta jala

Shadanga paneeya

In Charaka samhita siddha jala (medicated drinks) has been described as above. Ushna jala and Tiktaka shruta sheeta jala is advisable among specific jwara, but the Shadanga paneeya is useful in all kinds of jwara.(3)

\section{Shadanga Paniya}

The medicated water prepared with six medicinal herbs viz., musta, parpatak, usheera, chandana, uddichya, nagar is known as Shadanga paneeya.

\begin{tabular}{l|l|l|l|l|l|l|} 
& Musta(12) & Parpatak(13) & Usheera(14) & Chandan(15) & Udichya(16) & Nagar(17) \\
\hline Latin & $\begin{array}{l}\text { Cyperus } \\
\text { rotundus } \\
\text { Linn. }\end{array}$ & $\begin{array}{l}\text { Fumaria parviflora } \\
\text { Lam. }\end{array}$ & $\begin{array}{l}\text { Vetiveria } \\
\text { zizanoides } \\
\text { (Linn) Nash }\end{array}$ & $\begin{array}{l}\text { Santalum album } \\
\text { Linn }\end{array}$ & $\begin{array}{l}\text { Pavonia odorata } \\
\text { Willd }\end{array}$ & $\begin{array}{l}\text { Zingiber } \\
\text { officinale } \\
\text { Roscoe }\end{array}$ \\
\hline Family & $\begin{array}{l}\text { Cyperaceae } \\
\text { Rasa }\end{array}$ & Fumariaceae & Graminae & Santalaceae & Malvaceae & Scitaminae \\
\hline $\begin{array}{l}\text { Tikta, katu } \\
\text { kashaya }\end{array}$ & Tikta & Tikta madhura & Tikta madhura & Tikta & Katu
\end{tabular}


International Journal of Ayurvedic Medicine, Vol 11 (4), 627-631

\begin{tabular}{|c|c|c|c|c|c|c|}
\hline Veerya & Sheeta & Sheeta & Sheeta & Sheeta & Sheeta & Ushna \\
\hline Vipaka & Katu & Katu & Katu & Katu & Katu & Madhura \\
\hline Guna & Ruksha laghu & Laghu & Ruksha laghu & Ruksha laghu & Ruksha laghu & $\begin{array}{l}\text { Guru, ruksha, } \\
\text { tikshna }\end{array}$ \\
\hline Dosha & $\begin{array}{l}\text { Kapha } \\
\text { pittahara, }\end{array}$ & Kaphapittahara, & Kaphapittahara, & Kaphapittahara, & kaphapittahara & $\begin{array}{l}\text { Vata } \\
\text { kaphahara, }\end{array}$ \\
\hline Karma & $\begin{array}{l}\text { grahi, dipana, } \\
\text { pachana, } \\
\text { lekhana }\end{array}$ & $\begin{array}{l}\text { trishna nigrahana, } \\
\text { grahi }\end{array}$ & $\begin{array}{l}\text { pachana, } \\
\text { stambhana }\end{array}$ & $\begin{array}{l}\text { varnya, } \\
\text { dahaprashaman }\end{array}$ & $\begin{array}{l}\text { Deepan, pachan, } \\
\text { hrallas. }\end{array}$ & $\begin{array}{l}\text { dipana, } \\
\text { bhedan }\end{array}$ \\
\hline
\end{tabular}

The overall analysis of the drugs among Shadanga paneeya is as follows.

\section{Rasa (Taste)}

Among the six drugs the predominant rasa is tikta (bitter), then madhura (sweet) and followed by katu (pungent) and kashay (astringent).Tikta rasa is the superior to mitigate the fever as it does the aamapachana, aamashayakledanashana, agnideepaka. Shadanga paneeya is having dominancy of tikta rasa, therefore useful to counteract the samprapti of jwara. As per doshic predominance, tikta mitigate the pitta dosha, Kashaya mitigate the kapha dosha and madhura mitigate the vata dosha. Therefore on analysis of rasa combination of shadanga paneeya, it is useful in all kinds of jwara.

\section{Guna (Properties)}

Among the six drugs the predominant guna are laghu, ruksha, followed by guru and teekshna. Laghu and Ruksha guna having the predominance of vayu, aakasha and agni mahabhutas. These properties are useful in depletion of aama. Due to these properties it is useful in santarpanottha jwara.

Guru property is useful in nourishment as it is having prithvi and aapa mahabhuta predominance. Due to this guna it is useful in kshataj, kshajay and vataj jwara. Teekshna guna by its nature works rapidly in body. Therefore combination of these properties in shadanga paneeya is applicable in all kinds of jwara.

\section{Veerya (Potency)}

The predominance of sheeta veerya is present among the drugs of shadanga paneeya along with lesser proportion of ushna veerya. Jwara is disease of ushna in nature therefore sheeta veerya drugs are useful in it. Also in conditions like sheetapurvak jwara (fever with chills) shadanga paneeya is useful as it contain ushna veerya drug also.

Visha (poison) are having ushna veerya in nature therefore shadanga paneeya by virtue of its sheeta veerya dominancy useful in vishaj jwara (fever due to poison or poisonous contact).

\section{Vipaka}

The drugs of shadanga paneeya having combination of katu and madhura vipaka with dominancy of katu vipaka. As katu vipaka does the aamapachana, aamashayakledanashana useful in all kinds of jwara. Madhura vipaka is useful in vataj, bhayaja, shokaj jwara. Therefore the vipaka combination of shadanga paneeya is present in such a way that it is useful in all kinds of jwara.

\section{Karma (Pharamacological action)}

The pharamacological action of each drug is useful in breaking the etiopathogenesis of jwara. Almost all the drugs does the deepan pachan by which they are depleting aama. Parpataka (13) does the trishna nigrahana (pacifies the thirst), Chandana (15) does the dah prashaman (mitigates burning sensation), Musta (12) does the aamapachana, Usheera (14) does the pachana with pittashaman. Uddichya (16) does the dah prashaman (mitigates burning sensation), Shunthi (17) does the aamapachana, agnideepana.

So here the combination involved in shadanga paneeya is effective in dengue, typhoid and exhibiting antimalrial effect. These drugs are also exhibiting the antimicrobial effect by which they are useful in pyrexia caused by the infections of those microbes.

Advance researches has also revealed the antipyretic effect of these drugs.

\section{Musta (Cyperus rotundus Linn.) (18)}

The Cyperus rotundus tubers from which the isolation of patchoulenone, caryophyllene or-oxide, 10, 12-peroxycalamenene and 4, 7-dimethyl-1-tetralone has been done. These compounds had shown the antimalarial activities as the higher efficacy at ECso $2.33 \times 10^{6} \mathrm{M}$

The Cyperus oil had shown the antibacterial activity among various micro organisms. The microorganisms viz., Klebsiella pneumoniae, Proteus vulgaris, Streptococcus pyogenes, E. coli and P. aeruginosa, S.Aureus were studied by using inhibition zone method (Aromatogram). The MIC and MBC for each microbe were estimated. The oil of Cyperus rotundus was shown an efficacy over the bacteria, in which efficacy was more among the Grampositive bacteria, as compared to Gram-negative bacteria. The bacteria leads to the infection in the body. Any infection in the body leads to the pyrexia, as musta has shown antibacterial activity for various micro organisms the drug is useful for pyrexia.

\section{Parpataka (Fumaria parviflora Lam.)(19)}

Fumaria indica (parviflora) possesses the two major phytochemicals Narlumicine and Oxysanguinarine, these two are efficacious in the inhibition of dengue virus (DENV). The binding affinity is more than eight $\mathrm{kcal} / \mathrm{mol}$ against DENV4NS4B. These phytochemicals are highly reactive in the 
binding the pocket of DENV4- NS4B, based on ELUMO, EHOMO and band energy gap.

\section{Usheera (Vetiveria zizanoides (Linn.) Nash.) (20)}

Extract of Vetiveria zizanoides at $75 \mathrm{mg}, 150 \mathrm{mg}$ and $300 \mathrm{mg} / \mathrm{kg}$ dose had shown the significant reduction in the elevated temperature which was occurred due to the subcutaneous injection of yeast suspension ( $10 \mathrm{ml} / \mathrm{kg}$ body weight).

\section{Chandana (Santalum album Linn.):(21)}

The oil of the Santalum album had shown an effective antibacterial effect against Methicillin resistant Staphylococcus aureus and antimycotic resistant Candida species. The oil also exhibits the inhibition against Herpes simplex virus Type 1. The santalol has shown the anti-influenza activity against H3N2 virus. Methanol extract of Santalum album effective against Bacillus subtilis, Salmonella typhi, Staphylococcus aureus and Pseudomonas aeruginosa and highly active against Candida albicans.

\section{Uddichya (Pavonia odorata Willd.) (22)}

Pavonia odorata has shown the good antimicrobial activity against S.aureus, Diplococcus pneumonia, Chrysoporium indicum and Botrydiplodia sps.

\section{Nagar (Zingiber officinale Roscoe.)(23)}

An ethanolic extract of Zingiber officinale was shown the anti-inflammatory, analgesic, antipyretic, antimicrobial and hypoglycaemic activities. In rats, the extract of Zingiber officinale had shown the reduction in the carrageenan-induced paw swelling and yeastinduced fever. The Zingiber officinale had shown the efficacy in the inhibition of the growth of both Grampositive and Gram negative bacteria.

\section{Discussion}

In Charaka samhita nidana has been described separately for each types of fever. In Sushruta samhita the common cause for nija jwara have been described. Stanyavaran as a cause for jwara have been described in Sushruta samhita. Both the treatise considers the rasawaha and swedavaha strotas involvement in occurrence of fever. The description of specific prodromal signs as per the involvement of doshas is the contribution of Sushruta samhita. The treatment principle as per prodromal signs, aamavastha has been described in both samhitas. In Sushruta samhita administration of specific medicine as per the dosha involvement in prodromal stage have been described viz., vataj- pure ghee, pittaj- virechana, kaphaja mrudu prachachardhana. The description about treatment as per the stages viz., purvarupa, Aamashaya samuttha, jeerna jwara have been described in both samhitas.

The paneeya has been mentioned in charaka samhita in jwara as, as Ushna jala in vata kapha jwara, Tiktaka shruta sheeta jala in madyaja and paittika jwara, Shadanga Paneeya in all kinds of jwara. Shadanga contains six drugs, viz., musta, parpatak, usheera, chandana, uddichya, nagar. The conceptual analysis of shadanga paneeya in context with their Rasa, Guna, Veerya, Vipaka, Karma highlights the applicability in all kinds of jwara.

Shadanga contains six drugs, viz., musta, parpatak, usheera, chandana, uddichya, nagar. The every drug had shown the antimicrobial effect in different spectrum. The micro organisms are the responsible for the infection which in turns induces the fever. Hence the inhibition of the microorganism will control the infection and helpful in the reduction of fever.

The Cyperus rotundus was shown an efficacy over the Gram-positive bacteria, and Gram-negative bacteria. Parpataka is efficacious in the inhibition of dengue virus (DENV). Usheera is efficacious in fever due to yeast. Uddichhya is effective against S.aureus, Diplococcus pneumonia, Chrysoporium indicum and Botrydiplodia sps. The Santalum album is effective against Methicillin resistant Staphylococcus aureus and antimycotic resistant Candida species Herpes simplex virus Type 1e, H3N2 virus, Bacillus subtilis, Salmonella typhi, Staphylococcus aureus and Pseudomonas aeruginosa, Candida albicans. Zingiber officinale had shown the reduction in yeast-induced fever and shows the inhibition of the growth of both Gram-positive and Gram negative bacteria.

Hence the drugs of shadanga paneeya have also shown in researches the antipyretic effect ranging from dengue, malaria, typhoid to exhibition of antimicrobial effect.

\section{Conclusion}

Shadanga paneeya is a unique combination of different herbs, which by virtue of its combination of different Rasa, Guna, Veerya, Vipaka useful in all kinds of jwara. The combination possesses the antipyretic effect in all kinds of fever which are originating from viral, bacterial and parasitic origin. Therefore this is to conclude that shadanga paneeya as adjuvant medicated liquid is useful in all kinds of jwara.

\section{References}

1. Charaka samhita by Agnivesha revised by charaka and Dridhabala with the Ayurved Dipika commentary of Chakrapanidatta, Editor Acharya J.T., Chaukhambha Sanskrit Sansthan, Varanasi, fifth edition, 2001, pn. 193,

2. Charaka samhita by Agnivesha revised by charaka and Dridhabala with the Ayurved Dipika commentary of Chakrapanidatta, Editor Acharya J.T., Chaukhambha Sanskrit Sansthan, Varanasi, fifth edition, 2001, pn.398,

3. Charaka samhita by Agnivesha revised by charaka and Dridhabala with the Ayurved Dipika commentary of Chakrapanidatta, Editor Acharya J.T., Chaukhambha Sanskrit Sansthan, Varanasi, fifth edition, 2001, pn.410.

4. Charaka samhita by Agnivesha revised by charaka and Dridhabala with the Ayurved Dipika commentary of Chakrapanidatta, Editor Acharya 
J.T., Chaukhambha Sanskrit Sansthan, Varanasi, fifth edition, 2001, pn.399,

5. Sushrutasamhita of Sushruta with nibandhasangraha commentary of sri Dalhanacharya, Editor Acharya J.T. and Acharya N.R., Chaukhambha orientalia, Varanasi, fifth edition 1992, pn.671.

6. Charaka samhita by Agnivesha revised by charaka and Dridhabala with the Ayurved Dipika commentary of Chakrapanidatta, Editor Acharya J.T., Chaukhambha Sanskrit Sansthan, Varanasi, fifth edition, 2001, pn.199-201.

7. Sushrutasamhita of Sushruta with nibandhasangraha commentary of sri Dalhanacharya, Editor Acharya J.T. and Acharya N.R., Chaukhambha orientalia, Varanasi, fifth edition 1992, pn.672, 673.

8. Charaka samhita by Agnivesha revised by charaka and Dridhabala with the Ayurved Dipika commentary of Chakrapanidatta, Editor Acharya J.T., Chaukhambha Sanskrit Sansthan, Varanasi, fifth edition, 2001, pn.400.

9. Sushrutasamhita of Sushruta with nibandhasangraha commentary of sri Dalhanacharya, Editor Acharya J.T. and Acharya N.R., Chaukhambha orientalia, Varanasi, fifth edition 1992, pn.673.

10. Charaka samhita by Agnivesha revised by charaka and Dridhabala with the Ayurved Dipika commentary of Chakrapanidatta, Editor Acharya J.T., Chaukhambha Sanskrit Sansthan, Varanasi, fifth edition, 2001, pn.203.

11. Sushrutasamhita of Sushruta with nibandhasangraha commentary of sri Dalhanacharya, Editor Acharya J.T. and Acharya N.R., Chaukhambha orientalia, Varanasi, fifth edition 1992, pn.679-681.

12. Dravyagunavignana, volume II, Shastry J.L.N., Chaukhambha orientalia, Varanasi Reprint edition, 2015, p.n. 551, 554.
13. Dravyagunavignana, volume II, Shastry J.L.N., Chaukhambha orientalia, Varanasi Reprint edition, 2015, p.n.592, 593.

14. Dravyagunavignana, volume II, Shastry J.L.N., Chaukhambha orientalia, Varanasi Reprint edition, 2015, p.n.558, 559.

15. Dravyagunavignana, volume II, Shastry J.L.N., Chaukhambha orientalia, Varanasi Reprint edition, 2015, p.n.478, 480.

16. Bhavaprakashnighantu, Pandey G.S., Chaukhambha Bharati Academy, Varanasi, Reprint 2013, p.n.227.

17. Dravyagunavignana, volume II, Shastry J.L.N., Chaukhambha orientalia, Varanasi Reprint edition, 2015, p.n.871, 872.

18. Imam $\mathrm{H}$. Zarnigar et al. The incredible benefits of Nagarmotha (Cyperus rotundus) Int $J$ Nutr Pharmacol Neurol Dis 2014;4:23-7.

19. Guna G. Pharmacological Activity of Fumaria indica - A Review. J Phytopharmacol 2017; 6(6):352-355.

20. Narkhede M.B.et al, An evaluation of anti pyretic potential of Vetiveria zizanoides(Linn.) root, Research journal of pharmacognosy and Phytochemistry, 2012, volume 4 issue1p.n.11-13.

21. Rakesh et al. Phytochemistry and pharmacology of santalum album 1.: a review, World Journal of Pharmaceutical Research Volume 4, Issue 10, p.n.1842-1876.

22. S.Bhavani, Review on Anti-Pyretics \& Analgesic Herbs in Siddha Medicine, J. Pharm. Sci. \& Res. 2015 Vol. 7(10), 812-817.

23. N Mascolo, Ethnopharmacologic investigation of ginger (Zingiber officinale), Journal of Ethnopharmacology, 1989, vol 27, issue1, p.n 129-140. 